\title{
The Impact of Religiosity on Tax Compliance among Turkish Self-Employed Taxpayers
}

\author{
Serkan Benk ${ }^{1,+, *}$, Tamer Budak ${ }^{2, \dagger}$, Bahadır Yüzbaşı ${ }^{1,+}$ and Raihana Mohdali ${ }^{3,+}$ \\ 1 Faculty of Economics and Administrative Sciences, Inonu University, Malatya 44280, Turkey; \\ bahadir.yuzbasi@inonu.edu.tr \\ 2 Faculty of Law, Inonu University, Malatya 44280, Turkey; tamer.budak@inonu.edu.tr \\ 3 UTM Razak School of Engineering and Advanced Technology, Universiti Teknologi Malaysia, \\ Kuala Lumpur 54100, Malaysia; raihana.kl@utm.my \\ * Correspondence: serkan.benk@inonu.edu.tr; Tel.: +90-422-377-4260 \\ + These authors contributed equally to this work.
}

Academic Editor: Klaus Baumann

Received: 18 December 2015; Accepted: 30 March 2016; Published: 6 April 2016

\begin{abstract}
The aim of this study is to explore the impact between religiosity and voluntary tax compliance and enforced tax compliance for self-employed taxpayers in Turkey, where Islam is the predominant religion. A questionnaire survey was administrated to 375 male and 28 female self-employed taxpayers. In this paper, two dimensions of religiosity, namely interpersonal and intrapersonal religiosity, were studied. Factor analysis and ordinary least squares regression methods were used for data analyses. The results of the study illustrate that general religiosity has a statistically positive impact on both voluntary and enforced tax compliance. When we consider the dimensions of religiosity, only intrapersonal religiosity appears to be a significant contributor only to voluntary tax compliance. Nevertheless, interpersonal religiosity has no significant statistical effect on both voluntary and enforced tax compliance. This is one of the pioneer studies of its kind, and investigates the relationship between religiosity and tax compliance from the perspective of developing countries, particularly, Turkey.
\end{abstract}

Keywords: religiosity; interpersonal religiosity; intrapersonal religiosity; voluntary tax compliance; enforced tax compliance; ordinary least squares regression; Turkey

\section{Introduction}

The major purpose of taxation is to support fiscal and non-fiscal aims of a government. In this aspect, tax remains the most important source of revenue to almost all governments whether in developed or developing countries. Hence, it is crucial for the government to ensure that people in the country are paying their taxes voluntarily. There are many factors that affect taxpayers' compliance attitudes as evident clearly in prior research. Historically, taxpayers are assumed to lean towards tax evasion and, thus, the main focus of the research is on the economic factors that can deter negative attitudes of taxpayers. Therefore, tax structures, such as tax audit, tax penalty, and tax rate, are widely explored. However, this approach has been criticized by other researchers because it fails to include the non-economic factors, such as the values that shaped taxpayers' attitudes. These values are mainly stemmed from the external values that are based on taxpayers' perceptions of government, tax authority, and society; and the internal values that come from taxpayers' his/herself such as family, culture and moral or religiosity.

The non-economic approach, on the other hand, assumes that almost all taxpayers are willing to pay taxes and prior research has focused on the factors that encouraged taxpayers to voluntarily comply with tax laws. In the early stage of this approach, the impact of religiosity on tax evasion or 
compliance has been neglected. Only recently has this factor been emphasized as something to be explored in order to provide better understanding in terms of the attitudes of taxpayers towards tax compliance. This is probably because, regardless of religion, religious faith is expected to provide an internal control for an individual to clearly distinguish between good and bad behavior. However, the limited study on the influence of religiosity on tax compliance was mainly conducted in developed countries and using secondary data.

Therefore, this study aims to explore the impact of taxpayers' religious values on their positive tax compliance attitudes, which are measured by voluntary and enforced tax compliance. This study will also try to improve the understanding on taxpayers' complex attitudes from a different perspective, which is that of a developing country, namely Turkey, and using the primary data collected from self-employed taxpayers. The remainder of the paper is organized as follows. The next section briefly reviews the theoretical background regarding the influence of religiosity in tax compliance studies. This discussion is then followed by the presentation of the method used in this study. Next, the results of the study are presented and the final section concludes the paper.

\section{Theoretical Background and Research Hypotheses}

A combination of the economic and non-economic approaches, also known as the fiscal psychological approach, is suggested by a number of researchers (for example, [1,2]). The term "fiscal psychology" is introduced to emphasize the lack of motivation for taxpayers to pay taxes because there is no apparent gain from the benefit of tax payment, either in the form of monetary or public goods [1]. Tax morale, which is defined as an individual's internal motivation from religious beliefs or moral values, has been highlighted as one of the important elements in shaping taxpayers attitudes in this approach [3]; this is because the choice to comply or to evade, not only rests on the economic factors, but also on a set of attitudes and norms towards the fiscal system [4]. Even though religiosity has been emphasized in earlier tax research, the study on religiosity in tax research is still limited and further research was only strongly suggested after the year 2000 [5]. Responding to the recommendation made by Riahi-Belkaoui, an extensive research of religiosity in tax morale was commenced by Torgler and other researchers, mainly using secondary data from various sources, such as the European Values Survey and the World Values Survey, by covering a number of countries in their studies, such as Canada, Germany, Asian countries such as Bangladesh and Japan, most of the European countries such as Belgium, Spain, Turkey, the USA, and covered more than 30 other countries [6-12]. Despite the fact that setting plays an important role in understanding taxpayers' attitudes in abiding to tax law, little is known about them in developing countries [13]. The coverage of this research appears to lean towards developed countries, such as the USA, Australia, and Belgium. Overall, religiosity is found to have a positive impact on taxpayers' morale in these studies and is evident as one of the elements that forms tax morale, as clearly shown in Figure 1 [14].

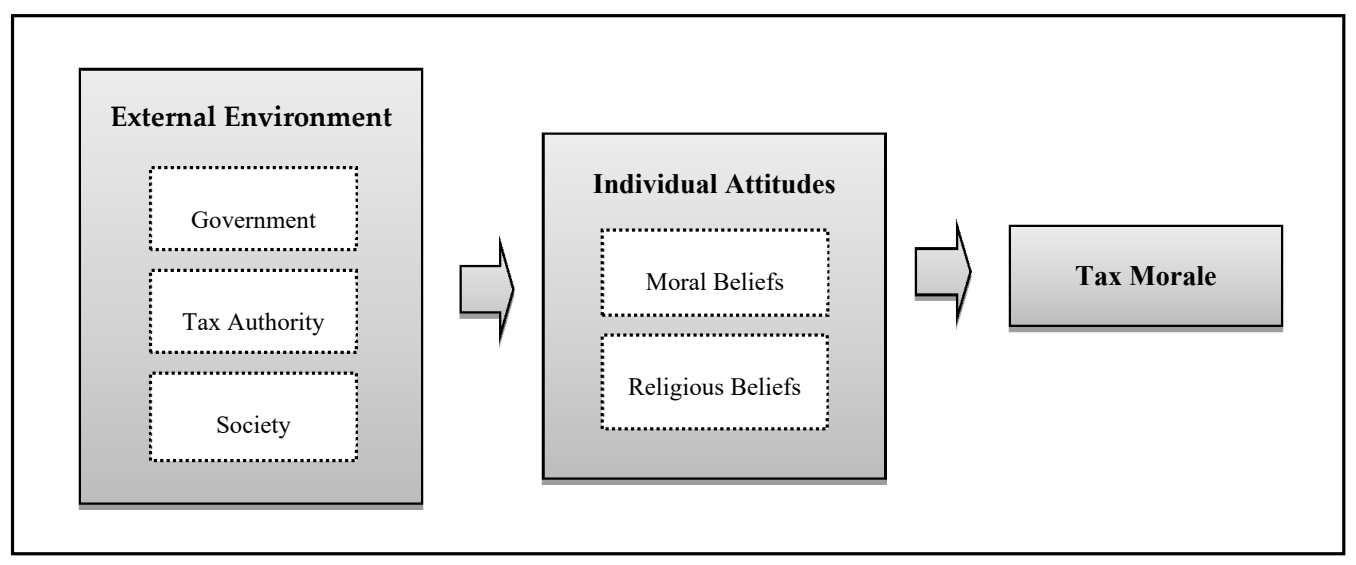

Figure 1. Main influences in the formation of tax morale (adapted from ([14], p. 570)). 
Religiosity was commonly viewed in previous research using two religious orientations, which are religious affiliation and religious commitment. Religious affiliation is the self-identified association of a person to a religion, such as being a Muslim, Christian, or Buddhist. Religious commitment is defined as "the degree to which a person adheres to his/her religious values, beliefs and practices, and uses them in daily living" ([15], p. 85). Religious commitment is divided into two types, namely intrapersonal religiosity that originates from the beliefs and attitudes of an individual; and interpersonal religiosity that develops from the involvement of an individual with a religious community or organization. Among the measurements used to represent religiosity commitment in previous research are church attendance, church participation, religious education, religious beliefs, importance of religion, religious guidance, and trust in church to represent religious observance (for example, [12]). However, these measurements are not linked clearly in prior studies, neither with intrapersonal nor with interpersonal religiosity, except for one study by Mohdali and Pope [16]. In other words, a significant positive influence of religiosity on tax compliance in prior research is solely based on the general religious commitment. Thus, not much understanding on which religious commitment dimension has a real impact on tax compliance.

The study by Mohdali and Pope investigates the impact of religiosity commitments (intrapersonal and interpersonal religiosity) on only one of the dimensions in tax compliance inventory, namely voluntary tax compliance that underlies taxpayers' behavioral intentions. Similar with the meaning of tax morale, as stated earlier, voluntary tax compliance emphasizes the willingness that is derived from the moral obligation to the public more [17]. However, they only employed primary data from the survey, distributed mainly to salaried taxpayers (90\%) and the rest are self-employed taxpayers and face-to-face interviews with participants from different religions. This might not provide a clear understanding of self-employed tax compliance attitudes because the opportunities to avoid or evade paying taxes between these two types of taxpayers are different. This is confirmed by Saez, who found that self-employed taxpayers have greater elasticity and more flexibility in reporting their incomes [18]. The findings of this study show a significant positive impact of religiosity on voluntary tax compliance; however, when comparing the findings between two dimensions of religiosity commitments, only intrapersonal religiosity indicates significant positive impact on voluntary tax compliance.

Overall, the perspective of taxpayers' compliance attitudes are explored from two different continuums, on one end are negative attitudes, such as tax evasion and tax avoidance, and on the other end is a positive attitude. The positive attitude is not only limited to tax morale or voluntary tax compliance, but also includes enforced tax compliance as proposed in the tax compliance inventory [17]. Enforced tax compliance happens when taxpayers are concern with being audited and fined by a tax authority. Hence, to understand taxpayers' complex compliance attitudes from the perspective of religiosity, it is crucial to truly understand their underlying intentions in paying taxes, whether they are voluntarily or enforced. Further, understanding those with more opportunities to evade, namely self-employed taxpayers, might provide more insight on how religious values influence attitudes. For the purpose of this study, the tax compliance dimensions involved only voluntary tax compliance and enforced tax compliance.

Based on the previously cited theoretical and empirical literature, the following test hypotheses involving religiosity are proposed:

$H_{1}$ : General religiosity affects all dimensions of tax compliance.

$H_{1 a}$ : General religiosity affects voluntary tax compliance.

$H_{1 b}$ : General religiosity affects enforced tax compliance.

$\mathrm{H}_{2}$ : Interpersonal religiosity affects all dimensions of tax compliance

$H_{2 a}$ : Interpersonal religiosity affects voluntary tax compliance

$H_{2 b}$ : Interpersonal religiosity affects enforced tax compliance

$H_{3}$ : Intrapersonal religiosity affects all dimensions of tax compliance

$\mathrm{H}_{3 a}$ : Intrapersonal religiosity affects voluntary tax compliance 
$H_{3 b}$ : Intrapersonal religiosity affects enforced tax compliance

\section{Methods}

\subsection{Participants}

In this study, respondents were randomly selected from self-employed taxpayers, from the city of Malatya, Turkey. Researchers visited the taxpayers in person and conducted the survey questionnaire. Participations in this study were voluntary and they were assured that their answers would remain confidential. In total, 408 of the 1550 questionnaire forms distributed to the self-employed taxpayers were returned and the response rate was $26.32 \%$. During the analysis, 403 responses were retained and 5 responses were omitted because the missing data in these responses was $95 \%$ or more. It is worth noting that this is a relatively high response rate compared to prior studies.

Table 1 shows the demographics of the study participants. The majority of the respondents $(58.80 \%)$ had a high school education, followed by $29.00 \%$ who had less than a high school education. The highest level of completed education is a graduate degree (achieved by $12.20 \%$ of the respondents). The sample consisted of $56.60 \%$ of respondents who are working in different trades, $41.90 \%$ who are working in the services sector, and $1.50 \%$ employed by other economic branches. The sample included $6.90 \%$ females and $93.10 \%$ males. The sample was divided into three age groups: (1) under $20(1.00 \%)$; (2) 21 to $40(68.00 \%)$; and (3) 41 or older (31.80\%). All respondents are Muslims.

Table 1. Demographics.

\begin{tabular}{ccc}
\hline Respondents & Sample Size: 403 & Percentage (\%) \\
\hline Education & & \\
\hline Less than high school & 117 & 29.0 \\
High school & 237 & 58.8 \\
Graduate & 49 & 12.2 \\
\hline Gender & & \\
\hline Male & 375 & 93.1 \\
Female & 28 & 6.9 \\
\hline Age & & \\
\hline Under 20 & 1 & 0.2 \\
$21-40$ & 274 & 68 \\
41 or older & 128 & \\
\hline Economic Branch & & 41.9 \\
\hline Services & 169 & 56.6 \\
Trade & 228 & \\
Other & 6 & 100.00 \\
\hline Religious Affiliation & & \\
\hline Islam & 403 & \\
\hline
\end{tabular}

\subsection{Measurement}

The questionnaire consisted of three sections. The first section was designed to obtain personal details of the respondent, such as level of education, gender, age, religious affiliation, and economic branch. Voluntary and enforced tax compliance statements were placed in the second section. The last section included the religiosity scale (see Appendix).

The independent construct in this study was taxpayers' religiosity, as measured by The Religious Commitment Inventory (RCI-10) [15]. The RCI-10 does not delve directly into the potentially sensitive and contentious theological religious realm, thus eliminating any possibility of offending participants or provoking their sensitivities [19]. The RCI-10 consisted of 10 items on a 5-point Likert scale ( $1=$ not at all true of me, $5=$ totally true of me). These items were divided into two religiosity commitments, 
intrapersonal and interpersonal, as presented in Table 2. The reliabilities of the two dimensions of The Religious Commitment Inventory were as follows: Intrapersonal religiosity ( 6 items; $\alpha=0.874$ ) and Interpersonal religiosity ( 4 items; $\alpha=0.681$ ).

Table 2. Descriptive statistics and reliability estimates.

\begin{tabular}{|c|c|c|c|c|c|}
\hline Variable & Overall Mean & Item No. & Alpha * & Mean & Std. Dev. \\
\hline \multirow{5}{*}{ Voluntary tax compliance (VTC) } & \multirow{5}{*}{6.604} & VTC1 & \multirow{5}{*}{0.931} & 6.980 & 2.05632 \\
\hline & & VTC2 & & 6.449 & 2.10880 \\
\hline & & VTC3 & & 6.395 & 2.27757 \\
\hline & & VTC4 & & 6.473 & 2.06997 \\
\hline & & VTC5 & & 6.796 & 1.87600 \\
\hline \multirow{5}{*}{ Enforced tax compliance (ETC) } & \multirow{5}{*}{6.304} & ETC1 & \multirow{5}{*}{0.781} & 5.861 & 2.01006 \\
\hline & & ETC2 & & 5.777 & 1.99371 \\
\hline & & ETC3 & & 6.452 & 1.79677 \\
\hline & & ETC4 & & 6.035 & 2.09114 \\
\hline & & ETC5 & & 7.422 & 2.30416 \\
\hline \multirow{4}{*}{ Interpersonal religiosity(InterR) } & \multirow{4}{*}{5.649} & InterR1 & \multirow{4}{*}{0.681} & 6.485 & 1.98021 \\
\hline & & InterR2 & & 6.246 & 2.02763 \\
\hline & & InterR3 & & 4.199 & 2.69667 \\
\hline & & InterR4 & & 5.637 & 2.20687 \\
\hline \multirow{6}{*}{ Intrapersonal religiosity(IntraR) } & \multirow{6}{*}{6.674} & IntraR1 & \multirow{6}{*}{0.874} & 6.325 & 1.84095 \\
\hline & & IntraR2 & & 5.819 & 1.86602 \\
\hline & & IntraR3 & & 6.729 & 1.68420 \\
\hline & & IntraR4 & & 8.156 & 1.53820 \\
\hline & & IntraR5 & & 6.702 & 1.67084 \\
\hline & & IntraR6 & & 6.402 & 1.73412 \\
\hline
\end{tabular}

* Reliability estimates reflect Cronbach's alpha; Std. Dev. = Standard Deviation.

The dependent variables, voluntary and enforced tax compliance, were measured based on 10 items on a 5-point Likert scale ( $1=$ strongly disagree, $5=$ strongly agree), adapted from the Tax Compliance Inventory (TAX-I) [17]. The voluntary dimension of tax compliance has 5 items and exhibited a reliability of 0.931 . The enforced dimension includes 5 items and has a reliability of 0.781 . The inter-item reliability estimates were above the recommended level of 0.60 , indicating acceptable convergent validity [20]. In addition, it was observed that none of the variables have a negative relationship with the total correlation. Thus, this finding has shown that the internal consistency of the data is considerably high.

\subsection{Factor Analysis}

Data collected were tested using three initial analyses: the correlation matrix, Bartlett's test of Sphericity, and the Kaiser-Meyer-Olkin measuring sampling adequacy to ensure it is appropriate to proceed with a factor analysis. Results of these three analyses support the factorability of the dataset. Evidence of the presence of the zero-order correlations among all items is moderately inter correlated (average range correlation $=0.175-0.691$ ) (see Table 3). Bartlett's test of Sphericity is 4692.69, $p<0.000$, and the Kaiser-Meyer-Olkin measure of sampling adequacy is 0.883 (see Table 4).

Table 3. Correlation matrix.

\begin{tabular}{ccccc}
\hline Construct & $\mathbf{1}$ & $\mathbf{2}$ & $\mathbf{3}$ & $\mathbf{4}$ \\
\hline 1.VTC & 1 & & & \\
2. ETC & $0.517^{* *}$ & 1 & & \\
3.InterR & $0.175^{* *}$ & $0.192^{* *}$ & 1 & \\
4.IntraR & $0.251^{* *}$ & $0.208^{* *}$ & $0.691^{* *}$ & 1 \\
\hline \multicolumn{6}{c}{$* * 0.01$}
\end{tabular}


Table 4. Factor analysis results.

\begin{tabular}{cccc}
\hline Item No. & Factor 1 & Factor 2 & Factor 3 \\
\hline IntraR6 & 0.778 & & \\
IntraR3 & 0.777 & & \\
IntraR4 & 0.762 & & \\
InterR2 & 0.755 & & \\
IntraR1 & 0.753 & & \\
InterR4 & 0.736 & & \\
InterR2 & 0.729 & & \\
IntraR5 & 0.654 & & \\
InterR1 & 0.640 & & \\
InterR3 & 0.306 & & \\
VTC5 & & 0.895 & \\
VTC1 & & 0.883 & \\
VTC4 & & 0.854 & \\
VTC2 & & 0.818 & \\
VTC3 & & 0.803 & \\
ETC2 & & & 0.883 \\
ETC1 & & & 0.857 \\
ETC4 & & & 0.634 \\
ETC3 & & & 0.581 \\
ETC5 & & & \\
Eigenvalue & 6.407 & 3.920 & 1.754 \\
Percent of Variance & 25.222 & 21.975 & 13.203 \\
Cumulative Percent & 25.222 & 47.197 & 60.401 \\
\hline
\end{tabular}

Kaiser-Meyer-Olkin Measure of Sampling Adequacy: 0.883; Barlett's Test of Spherecity (Chi-Square: 4692.69, $p<0.000)$.

All 20 items of scale were factor analyzed. The result of the factor analysis with Varimax Rotation and the criteria of eigenvalues $\geqslant 1$ indicated that the three factor solutions are found to be the most interpretable. The three-factor solution accounted for $60.40 \%$ of the total variance. The three factors and their respective items, factor loadings, eigenvalues, and percentage of variance, are presented in Table 4.

Factor 1 is labeled as "General Religiosity", and constitutes ten items, accounting for $25.222 \%$ of the total variance of the items. The item values loaded ranged from 0.306 to 0.778 . Factor 2 is labeled "Voluntary Tax Compliance", and constitutes five items and accounts for $21.975 \%$ of the total variance of the items. The item values loaded ranged from 0.803 to 0.895 . Factor 3 is labeled "Enforced Tax Compliance", and constitutes five items, accounting for $5.43 \%$ of the total variance of the items. The item values loaded ranged from 0.318 to 0.883 .

\section{Results}

In this paper, ordinary least squares (OLS) regression analyses were separately used to analyze data and to test the hypotheses with respect to general religiosity, intrapersonal religiosity, and interpersonal religiosity as independent variables, and voluntary and enforced tax compliance as dependent variables. Table 3 illustrates the correlation matrix for the independent and dependent variables. In order to examine the relationships between independent variables and dependent variables, four separate regressions analyses were run. To avoid the problem of heteroskedasticity, we estimated the regression coefficient by using the Newey-West estimator. This estimator can be used to improve the OLS regression when the residuals are heteroskedastic and/or autocorrelated [21]. Table 5 reports the results of these regression analyses for each of the four models. 
Table 5. Regression Analyses.

\begin{tabular}{|c|c|c|c|c|c|c|}
\hline & \multicolumn{3}{|c|}{ Model 1} & \multicolumn{3}{|c|}{ Model 2} \\
\hline \multirow[t]{2}{*}{ Independent Variable } & \multicolumn{3}{|c|}{$\begin{array}{l}\text { Dependent Variable: } \\
\text { Voluntary Tax Compliance }\end{array}$} & \multicolumn{3}{|c|}{$\begin{array}{c}\text { Dependent Variable: Enforced } \\
\text { Tax Compliance }\end{array}$} \\
\hline & $\beta$ & $t$-value & Sig. & $\beta$ & $t$-value & Sig. \\
\hline Intercept & 4.612 & $6.233^{* * *}$ & 0.000 & 4.781 & $8.480^{* * *}$ & 0.000 \\
\hline \multirow[t]{4}{*}{ Total Religiosity } & 0.318 & $2.832 * *$ & 0.004 & 0.242 & $2.928^{* *}$ & 0.003 \\
\hline & \multicolumn{3}{|c|}{$R^{2}=0.051$ Adj. $R^{2}=0.048$} & \multicolumn{3}{|c|}{$R^{2}=0.046$ Adj. $R^{2}=0.044$} \\
\hline & \multicolumn{3}{|c|}{$F(1,391)=21.405 p<0.000$} & \multicolumn{3}{|c|}{$F(1,391)=19.521 p<0.000$} \\
\hline & \multicolumn{3}{|c|}{ Model 3} & \multicolumn{3}{|c|}{ Model 4} \\
\hline \multirow[t]{2}{*}{ Independent Variables } & \multicolumn{3}{|c|}{$\begin{array}{l}\text { Dependent Variable: } \\
\text { Voluntary Tax Compliance }\end{array}$} & \multicolumn{3}{|c|}{$\begin{array}{c}\text { Dependent Variable: Enforced } \\
\text { Tax Compliance }\end{array}$} \\
\hline & $\beta$ & $t$-value & Sig. & $\beta$ & $t$-value & Sig. \\
\hline Intercept & 4.481 & $5.834^{* * *}$ & 0.000 & 4.670 & $7.767^{* * *}$ & 0.000 \\
\hline Interpersonal Religiosity & 0.051 & 0.526 & 0.598 & 0.033 & 0.335 & 0.737 \\
\hline \multirow[t]{3}{*}{ Intrapersonal Religiosity } & 0.274 & $2.226^{*}$ & 0.026 & 0.216 & 1.811 & 0.070 \\
\hline & \multicolumn{3}{|c|}{$R^{2}=0.053$ Adj. $R^{2}=0.048$} & \multicolumn{3}{|c|}{$R^{2}=0.049$ Adj. $R^{2}=0.044$} \\
\hline & \multicolumn{3}{|c|}{$F(2,390)=11.225 p<0.000$} & \multicolumn{3}{|c|}{$F(2,390)=10.348 p<0.000$} \\
\hline
\end{tabular}

Multiple regression analyses were performed to examine the influence of general religiosity on tax compliance components, namely voluntary tax compliance (Model 1) and enforced tax compliance (Model 2). The regression in Model 1 produces an adjusted $R^{2}=0.048, F(1,391)=21.405, p<0.000$, and Model 2 produces an adjusted $R^{2}=0.044, F(1,391)=19.521, p<0.000$. Similar findings are clearly evident in Model 1 and Model 2. In other words, the religious values held by Turkish Muslim taxpayers have a positive significant influence in shaping their tax-paying attitudes, either voluntarily or with enforcement by the tax authority. The findings are in line with almost all religiosity studies in tax evasion and tax compliance (e.g., [6-15]).Thus, hypotheses $H_{1 a}$ and $H_{1 b}$ are supported.

Even though the general religiosity has shown a positive impact on both dimensions of tax compliance, the findings for Model 3 and Model 4 have indicated that only intrapersonal religiosity appears to be a significant contributor to voluntary tax compliance, whereas interpersonal religiosity is an insignificant predictor for both dimensions of tax compliance. A significant model emerges with an adjusted $R^{2}=0.048, F(2,390)=11.225, p<0.000$ for Model 3. Likewise, Model 4 also appears as a significant model with an adjusted $R^{2}=0.044, F(2,390)=10.348, p=0.000$. The overall findings suggest that most taxpayers are using their intrapersonal values in voluntarily complying with tax laws. This is similar to the findings on voluntary tax compliance in prior research, although the types of taxpayers are different [16]. Thus, hypothesis $H_{3 a}$ is supported, but $H_{2 a}, H_{2 b}$, and $H_{3 b}$ are rejected.

\section{Conclusions}

The empirical evidence in this study has shown that religiosity, in general, has a minimal but significant and positive impact on taxpayers' attitudes. The findings of this study show that general religiosity explains approximately only five percent of taxpayers' willingness to comply with tax laws, and only four percent of their enforced tax compliance attitudes. These are supporting the causal relationships between religion and tax compliance, as discussed earlier, and also other economic outcomes (for example, [22,23]). However, examining the real impact of the two dimensions of religiosity commitments of tax compliance has demonstrated that only the intrapersonal has a significant impact on voluntary tax compliance, but not enforced tax compliance. At this point, 
it seems that the impact of general religiosity on voluntary tax compliance is strongly influenced by taxpayers' intrapersonal religiosity and is less likely to be influenced by taxpayers' interpersonal religiosity. This finding supports the study of religiosity on tax morale conducted by Torgler and other researchers. In other words, the findings of this study provide significant evidence that the definition of tax morale and voluntary tax compliance can be considered as similar since they can only be influenced by the inner values developed by religious practices or moral obligations. For example, in Islamic and Christian teaching, sadaqah (contribution) or tithing is highly encouraged in the nurturing of values of giving to the needy and these values are probably simply applied in contributing to the development of the nation by paying taxes. In other words, deterrent tools might not be effective for Turkish people since they are already have a strong willingness to fulfill their tax obligations to the country. Therefore, the tax authority is suggested to ensure that all the actions taken by the tax authority might not weaken taxpayers' strong tax morale, which is highly derived from their religious faith.

This study has several limitations. The main limitation arises from the sampling process used. The sample was drawn from only one city (Malatya, Turkey). The random selection of participants alleviates this concern to a significant degree, but does not completely remedy that shortcoming. The second limitation is related to the possibility of participants misunderstanding the questions and terminology used in the survey. The third limitation is in relation to moral values. This paper did not separate between religious attitudes and ethical values in measuring the source of taxpayers' inner values; there was a possibility that the respondents' inner values may be derived from both sources. Thus, comparing the effects of an individual's religiosity with an individual's ethical values, which have not been derived from religious attendance, on voluntary and enforced tax compliance is suggested for future research.

Future research can include some demographic variables (education, age, gender, etc.) in analyses. Thus, we can see how the demographic factors affect both religiosity and level of tax compliance. There is another potential for future research; which will be carried on for other countries and/or religions to assess if these dimensions of religiosity exist, and how these dimensions affect tax compliance behavior. Even with its limitations, this study has provided evidence that religiosity, particularly intrapersonal religiosity, is one of the factors that can shape taxpayers willingness to comply with tax laws, as well as those who need to be enforced with tax laws.

Author Contributions: Serkan Benk, Tamer Budak and Bahadır Yüzbaşı designed the study and conducted statistical analysis. Raihana Mohdali and Serkan Benk contributed to the analysis and writing. The final manuscript was approved by all authors.

Conflicts of Interest: The authors declare no conflict of interest.

\section{Appendix}

\section{Scale Items}

\section{Tax Compliance Items}

\section{A-Voluntary Tax Compliance (VTC)}

Q: When I pay my taxes as required by the regulations, I do so...

VTC1. ...because to me it's obvious that this is what you do

VTC2. ...to support the states or other citizens

VTC3. ...because I like to contribute to everyone's good

VTC4. ...because for me it's the natural thing to do

VTC5. ...because I regard it as my duty as citizen

\section{B-Enforced Tax Compliance (ETC)}

Q: When I pay my taxes as required by the regulations, I do so...

ETC1. ...because a great many tax audits are carried out

ETC2. ...because the tax office often carries out audits

ETC3. ...because I know that I will be audited 
ETC4. ...because the punishments for tax evasions are very severe

ETC5. ...because I do not know exactly how to evade taxes without attracting attention

\section{Religiosity Items}

\section{A-Interpersonal Religiosity (InterR)}

InterR1. I make financial contributions to my religious organization.

InterR2. I enjoy spending time with others of my religious affiliation.

InterR3. I keep well informed about my local religious group and have some influence in its decisions. InterR4. I enjoy working in the activities of my religious organization.

\section{B-Intrapersonal Religiosity (IntraR)}

IntraR1. My religious beliefs lie behind my whole approach to life.

IntraR2. I spend time trying to grow in understanding of my faith.

IntraR3. It is important to me to spend periods of time in private religious thought and reflection.

IntraR4. Religious beliefs influence all my dealings in life.

IntraR5. Religion is especially important to me because it answers many questions about the meaning of life.

IntraR6. I often read books and magazines about my faith.

\section{References}

1. Schmölders, Günter. “Fiscal Psychology: A New Branch of Public Finance." National Tax Journal 12 (1959): $340-45$.

2. Hasseldine, D. John, and K. Jan Bebbington. "Blending Economic Deterrence and Fiscal Psychology Models in the Design of Responses to Tax Evasion: The New Zealand Experience." Journal of Economic Psychology 12 (1991): 299-324. [CrossRef]

3. Schmölders, Gunter. "Survey Research in Public Finance: A Behavioral Approach to Fiscal Theory." Public Finance 25 (1970): 300-6.

4. Spicer, Michael W., and Scott B. Lundstedt. “Understanding Tax Evasion.” Public Finance 31 (1976): 295-305.

5. Riahi-Belkaoui, Ahmed. "Relationship between Tax Compliance Internationally and Selected Determinants of Tax Morale." Journal of International Accounting, Auditing and Taxation 13 (2004): 135-43. [CrossRef]

6. Torgler, Benno. "To Evade Taxes or Not to Evade: That is the Question." Journal of Socio-Economics 32 (2003): 283-302. [CrossRef]

7. Feld, Lars P., and Benno Torgler. Tax Morale After the Reunification of Germany: Results from a Quasi-Natural Experiment. Munich: CESifo, 2007.

8. Torgler, Benno. "Tax Morale in Asian Countries." Journal of Asian Economics 15 (2004): 237-66. [CrossRef]

9. Torgler, Benno, and Friedrich Schneider. "What Shapes Attitudes Toward Paying Taxes? Evidence from Multicultural European Countries*." Social Science Quarterly 88 (2007): 443-70. [CrossRef]

10. Torgler, Benno, Ihsan C. Demir, Alison Macintyre, and Markus Schaffner. "Causes and Consequences of Tax Morale: An Empirical Investigation." Economic Analysis and Policy 38 (2008): 313-39. [CrossRef]

11. Torgler, Benno. "Attitudes toward Paying Taxes in the USA: An Empirical Analysis The Ethics of Tax Evasion." In The Ethics of Tax Evasion: Perspectives in Theory and Practice. Edited by Robert W. McGee. New York: Springer, 2012, pp. 269-83.

12. Torgler, Benno. "The Importance of Faith: Tax Morale and Religiosity." Journal of Economic Behavior \& Organization 66 (2006): 81-109. [CrossRef]

13. Hungerman, Daniel M. "Public Goods, Hidden Income, and Tax Evasion: Some Nonstandard Results from the Warm-glow Model." Journal of Development Economics 109 (2014): 188-202. [CrossRef]

14. Pope, Jeff, and Raihana Mohdali. "The Role of Religiosity in Tax Morale and Tax Compliance." Australian Tax Forum 25 (2010): 565-96.

15. Worthington, Everett L., Jr., Nathaniel G. Wade, Terry L. Hight, Jennifer S. Ripley, Michael E. McCullough, Jack W. Berry, Michelle M. Schmitt, James T. Berry, Kevin H. Bursley, and Lynn O'Connor. “The Religious Commitment Inventory-10: Development, Refinement, and Validation of a Brief Scale for Research and Counseling." Journal of Counseling Psychology 50 (2003): 84-96. [CrossRef] 
16. Mohdali, Raihana, and Jeff Pope. “The Influence of Religiosity on Taxpayers' Compliance Attitudes: Empirical Evidence from a Mixed-Methods Study in Malaysia." Accounting Research Journal 27 (2014): 71-91. [CrossRef]

17. Kirchler, Erich, and Ingrid Wahl. “Tax Compliance Inventory: TAX-I Voluntary Tax Compliance, Enforced Tax Compliance, Tax Avoidance, and Tax Evasio." Journal of Economic Psychology 31 (2010): 331-46. [CrossRef] [PubMed]

18. Saez, Emmanuel. “Do Taxpayers Bunch at Kink Points?" American Economic Journal: Economic Policy 2 (2010): 180-212. [CrossRef]

19. Mokhlis, Safiek. "Relevancy and Measurement of Religiosity in Consumer Behavior Research." International Business Research 2 (2009): 75-84. [CrossRef]

20. Carmines, Edward G., and Richard A. Zeller. Reliability and Validity Assessment. Beverly Hills: Sage Publications, 1979.

21. Newey, Whitney K., and Kenneth D. West. "Automatic lag selection in covariance matrix estimation." Review of Economic Studies 61 (1994): 631-54. [CrossRef]

22. Gruber, Jonathan H. "Religious Market Structure, Religious Participation, and Outcomes: Is Religion Good for You?" The B.E. Journal of Economic Analysis \& Policy 5 (2005): 1-30. [CrossRef]

23. Hungerman, Daniel M. “Do Religious Proscriptions Matter? Evidence from a Theory-Based Test." Journal of Human Resources 49 (2014): 1053-93. [CrossRef]

(C) 2016 by the authors; licensee MDPI, Basel, Switzerland. This article is an open access article distributed under the terms and conditions of the Creative Commons by Attribution (CC-BY) license (http:/ / creativecommons.org/licenses/by/4.0/). 